\title{
Domestic violence against women, Islamic Republic of Iran: a grounded theory study
}

Naghmeh Razaghi, ${ }^{1}$ Monir Ramezani, ${ }^{1}$ Soroor Parvizi ${ }^{2}$ and Seyed Mohammad Tabatabaee Nejad ${ }^{3}$

${ }^{1}$ Nursing and Midwifery Care Research Center, Mashhad University of Medical Sciences, Mashhad, Islamic Republic of Iran. ${ }^{2}$ Department of Pediatric Nursing, School of Nursing and Midwifery, Iran University of Medical Sciences, Tehran, Islamic Republic of Iran. ${ }^{3}$ Legal Medicine Organization of Mashhad, Mashhad, Islamic Republic of Iran. (Correspondence to: Monir Ramezani: ramezanimn@mums.ac.ir).

\begin{abstract}
Background: Although a silent phenomenon, violence against women has been well studied. Such violence is a universal problem with different regional and cultural patterns; it imposes heavy costs on society.

Aims: This study aimed to assess the circumstances and features of domestic violence against women in Mashhad, Islamic Republic of Iran.

Methods: This was a qualitative study using the grounded theory approach. Individual semi-structured interviews were held with 24 purposely selected women who had experienced domestic violence and who had gone to the Legal Medicine Organization of Mashhad for help. Data were analysed according to grounded theory.

Results: From analysis of the interview data, seven main categories emerged: risk factors of violence; protective factors against violence; excuses for violence; behavioural and cultural challenges in men; inevitable adjustment; escalation of violence; and presenting to legal medicine organizations. Constant comparative analysis of the data led to the identification of inevitable adjustment as the core variable of the study.

Conclusions: Inevitable adjustment was the main strategy of women to deal with domestic violence against them. Promoting respect for the universal human rights of women, strengthening the network of services and social support for women and enforcing legal protection are necessary to reduce violence against women.

Keywords: domestic violence, risk factors, protective factors, grounded theory, Iran

Citation: Razaghi N; Ramezani M; Parvizi S; Tabatabaee Nejad S. Domestic violence against women, Islamic Republic of Iran: a grounded theory study. East Mediterr Health J. 2022;28(4):281-287. https://doi.org/10.26719/emhj.22.033

Received: 21/03/21; accepted: 06/10/21

Copyright (c) World Health Organization (WHO) 2022. Open Access. Some rights reserved. This work is available under the CC BY-NC-SA 3.o IGO license (https://creativecommons.org/licenses/by-nc-sa/3.o/igo)
\end{abstract}

\section{Introduction}

Violence is a legal, health and human problem at the international level. Women who are subjected to violence feel extremely humiliated irrespective of their race, age, ethnicity and nationality (1). According to the World Health Organization (WHO), violence against women affects $30 \%$ of women across the world (2). The problem of violence against women is closely associated with sociocultural variables and goes beyond geographical, religious and socioeconomic boundaries (3). Women are not the only victims of violence; children of mothers subjected to violence also feel anger, discomfort and shame. These children are highly vulnerable to abuse and may also attack others. According to an annual report by the United Nations Children's Fund, US\$ 5-10 billion are directly spent by governments in dealing with domestic violence in the United States, while the cost is more noticeable in developing countries (4).

Although the problem of violence against women is universal, it has regional and cultural patterns and often remains secret (5). This type of violence is as a public health problem in view of the consequences on women's reproductive health and physical and mental health. Research suggests violence is associated with physical damage, chronic fear syndrome, disabilities, suicide, homicide, sexual harassment, pregnancy complications, severe depression, and drug abuse $(6,7)$.

A systematic review of 16 studies presented evidence from countries of the East Mediterranean Region on factors associated with physical domestic violence. The findings showed that young age of women at the time of marriage, anger issues in men, belief in the superiority of men and men's exposure to domestic violence in childhood were predisposing factors to domestic violence. On the other hand, consanguinity, women's university education and women's employment in well paid jobs were protective factors (8).

Although a silent phenomenon, violence against women has been much studied and many statistics are available on it (9). A study conducted in Arab and Islamic countries suggests that at least one in three women is subjected to violence by their husbands (10). Review of published evidence found the global prevalence of physical or sexual partner violence among ever-married women to be about $30 \%$, with the highest prevalence (37\%) in the African, Eastern Mediterranean and SouthEast Asia regions (2,11).

As with other countries, the abuse of women is an important public health and social challenge in the Islamic Republic of Iran, where the prevalence of 
domestic violence is estimated to be $66 \%$. In addition, by geographical classification, the prevalence of domestic violence was 70\% in the east of the country (12).

Most studies conducted on violence against Iranian women are correlation studies (13). Moreover, given the extent and importance of the problem, a comprehensive and open-minded view is crucial to understanding and resolving domestic violence against women (14). Grounded theory is a powerful research technique for studying social structures and processes in their own context (15). Given the role of sociocultural factors in violence against women and since most of the studies on the subject are quantitative, we aimed to assess the circumstances and features of domestic violence against Iranian women in Mashhad, the capital city of Khorasan Razavi Province in north-eastern Islamic Republic of Iran.

\section{Methods}

The grounded theory approach was used to identify the hidden social processes and variables that shape and affect domestic violence against women $(16,17)$. Qualitative research is conducted in an actual natural setting (18). In our study, we held interviews at the Legal Medicine Organization of Mashhad because of its ease of access for female victims of violence. This organization is a centre for victimized women to help them deal with legal proceedings and to get the extent of the damage caused by domestic violence investigated by officers. The organization is also responsible for the judgement and expert analysis of forensic affairs and for performing autopsy and laboratory and clinical tests requested by competent judicial authorities.

To collect data, we used purposive sampling to select individuals who had experienced domestic violence (19). Thus we selected 24 women presenting to the Legal Medicine Organization for domestic violence. Data collection and analysis continued with theoretical sampling to complement and develop a theory (20). The interviews continued until data saturation was reached and no new codes emerged.

We held semi-structured interactive interviews with the participants individually in a quiet and comfortable room at the Legal Medicine Organization. Interviews lasted half an hour to 2 hours depending on the circumstances. First, we asked the participants about their personal details. Then, we used a guiding interview as the primary framework for beginning the interviews. Some of the guiding questions asked included: "Under what exact conditions do you often fall victim to domestic violence?" and "Please describe the conditions under which you have fallen victim to domestic violence".

The verbal communication between the participants and the interviewer was audio-recorded and promptly transcribed verbatim. All the non-verbal communication was also noted. The data were encoded and analysed according to the Strauss and Corbin approach (17). In the first step, the data obtained from the interview transcripts were broken into small parts as codes. Data similarities and differences were then compared through the constant comparative method. Data were then put in clusters. Categories emerged in the second step of data coding. New data were simultaneously compared with all the existing data to identify an optimal core variable. Finally, a theory describing participants' experience of domestic violence was generated and a core variable was chosen during the selective coding stage. The transcribed interviews filled 120 pages and led to the identification of seven main categories.

To ensure data robustness and accuracy, we used maximum variation sampling (18). We dedicated enough time to data collection and held more than one interview with each participant if necessary. We also ensured interviewers built a good rapport with the participants and performed external checks, member checks and peer checks (18).

\section{Ethical considerations}

We registered the study with the Legal Medicine Organization of Mashhad. The Iranian Legal Medicine Research Centre approved the research (code 2820). We obtained written informed consent from the participants, ensured confidentiality of the data and anonymity of the participants (using codes to identify them), allowed participants to withdraw from the study at their own discretion and provided the participants with the results of the study on their request.

\section{Results}

\section{Participants' personal details}

Of the 24 women who participated in this study, 5 were aged 17-20 years, 9 were $21-30$ years, 6 were $31-40$ years and 4 were 41-44 years. Two women had previously been married and 21 were in their first marriage. One woman was single and had been subjected to violence by her brother and the rest were married and had been subjected to violence by their husband. Their duration of marriage was between 6 months and 23 years, with a mean of 9.5 years. In terms of the level of education, 14 of the women were illiterate, 8 had a high-school diploma and 2 had a university education. Analysis of the data extracted from the interviews resulted in seven main categories and a number of subcategories (Box 1).

\section{Risk factors of violence}

According to the participants' experiences, the risk of violence was influenced by: woman's young age at the time of marriage, woman's low level of education, woman's lack of financial independence, man's exposure to violence in childhood, interference of the spouse's family in the couple's life, and low economic status.

In this regard, the husband's failure to assume responsibility, take care of his wife and children and earn a living for them led to the woman's exasperation, and when she protested, the husband resorted to violence and fighting. Participant 9, a 29-year-old woman, said, "For 8 


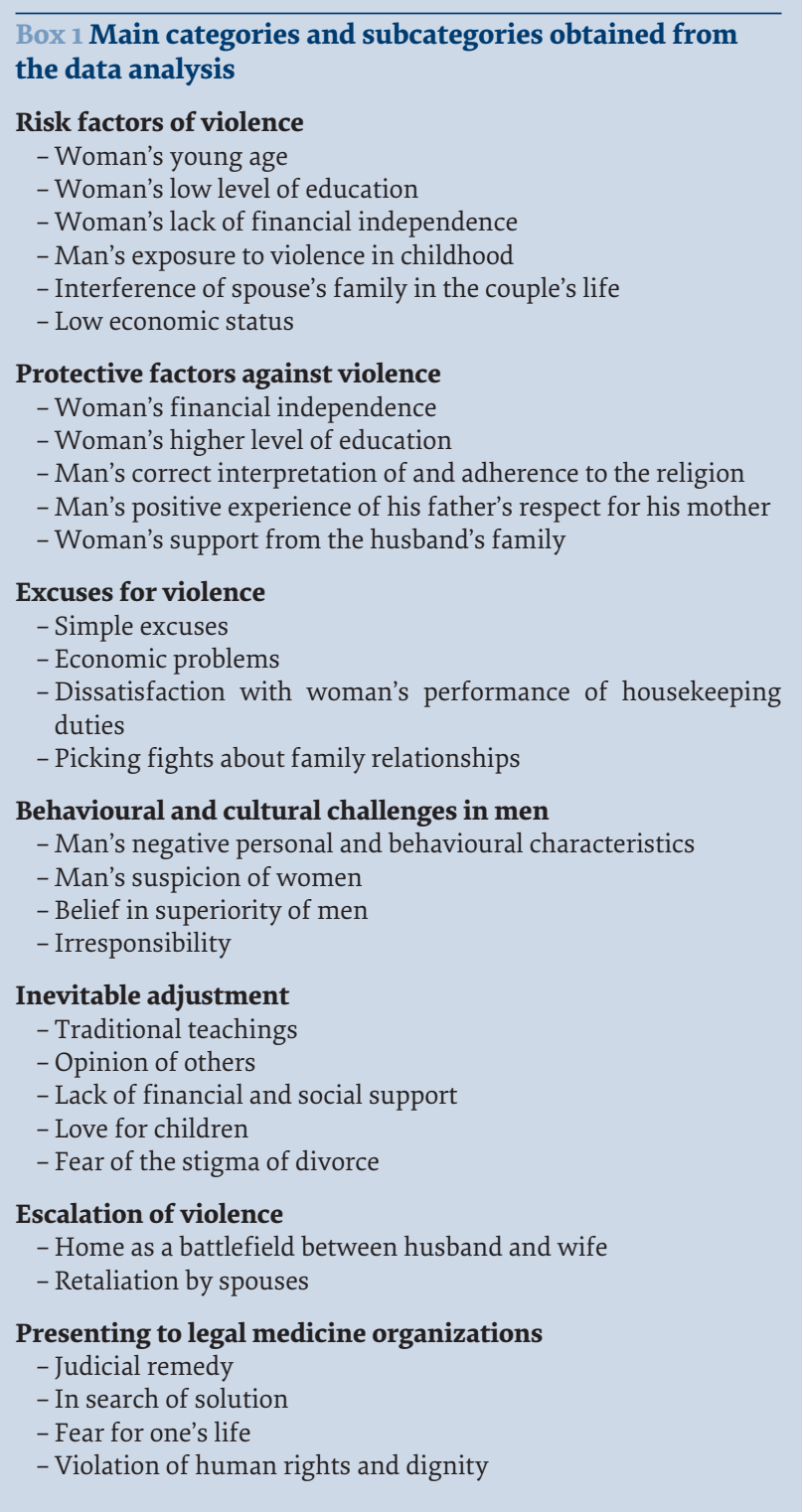

years, my husband paid neither my alimony nor our living expenses. This man feels absolutely no responsibility towards his family. He tells me to take it or leave it. If I protest, he beats me up".

\section{Protective factors against violence}

Factors that protected against domestic violence included: woman's financial independence and higher level of education, man's correct interpretation of and adherence to the religion, man's positive experience of his father's respect for his mother, and woman's support from her husband's family. Participant 15, a 23-year-old woman, said, "I saw that in families that really adhere to the religion and know the rights of women from the point of view of Islam, women are always respected".

\section{Excuses for violence}

Violence was triggered by simple and ordinary issues, such as the husband's dissatisfaction with the wife's cooking or the food prepared, housekeeping duties, fatigue taken home from the outside and the wife's or children's lack of obedience to the husband or father. Economic problems were often the triggers of violence. Participant 11, a 37-year-old woman, disclosed that unpaid debts and checks being due were the triggers of violence in her home and said, "Usually he looks for an excuse to beat me when he's got debts to pay".

\section{Behavioural and cultural challenges in men}

Men's negative personal and behavioural characteristics played a key role in their interactions and relationships with their wives. A husband's suspicion and mistrust of women, a bad temper, aggressiveness, anger or inability to control one's anger, and irresponsibility were among the characteristics most of the participants had witnessed in their husband. Participant 2, a 16-year-old woman, said, "My husband wants me to go outside only with him, listen to everything he says, and agree with whatever he says. If I disagree, he only beats or insults me".

Societal understanding of masculinity, including belief in the superiority of men and that women are part of a man's property and they have control over women, can lead to violent behaviour and physical and psychological harm to women. Participant 3, a 21-year-old woman, said, "From childhood, men are raised in such a way that they are convinced that they are the superior sex and women should be obedient to men".

\section{Inevitable adjustment}

When faced with violence, women first tried to retaliate, but eventually admitted that they could not escape this ugly and unpleasant reality and believed that they had to work hard to keep their marriage. At this stage, they inevitably chose to adjust. They expressed their forced acceptance of violence in their private life with terms such as coercion or desperation. Several factors played a role in women's inevitable adjustment and eventual "decision" to stay in a violent relationship such as: traditional teachings about the expectations of women in the family, the opinion of others, lack of financial and social support, having a child, and fear of the stigma of divorce.

Traditional teachings hold that women should be calm and patient, do their best to keep their marriage and continue with their married life under all circumstances. Participant 3, a 21-year-old woman, said, "My mother tells me to just go on with my life and that all marriages are the same".

At times, the fear and sadness the women felt as a result of the opinion of others were deeper than their annoyance with the violence itself. As a result, they tried to hide that they were being subjected to violence to avoid the negative attitudes of other people. Participant 20, a 19-year-old woman, said, "''ll feel embarrassed if someone finds out I've been beaten up or yelled at by my husband. They will blame me and think I've been guilty, although I've been innocent".

Lack of financial and social support was another aspect of the inevitable adjustment made by the victims of domestic violence. Participant 5, a 26-year-old woman, 
said, "I have to keep my marriage because I have no financial support."

Children were another reason for the women's adjustment to violence and endurance of it. Participant 16, a 23-year-old woman, said, "I'm enduring my husband's violence and living with him just because of my child; I'm living a forced life".

Fear of the stigma of divorce also led to women enduring domestic violence. Participant 20, a 19-year-old woman, said, "Society's view of divorced women is not good at all. I prefer to tolerate this violent relationship and not be a divorced woman in Iranian society".

\section{Escalation of violence}

Unilateral violence gradually turned the home into a battlefield. The women felt despondent, weak, helpless, coerced, stressed and anxious as a result of repeated episodes of violence. They felt oppressed and feeble and, whether consciously or unconsciously, sought revenge in an effort to defend at least parts of their rights. They found themselves in a position of frequent and bitter argument with their husband which further fuelled the violence. Participant 15, a 23-year-old woman, said, "We always argue. He beats me up and sometimes even threatens me. Once, there was boiling hot water on the heater and he wanted to pour it over me. So I told him I'd break everything he had into pieces if he did that. I started breaking the dishes and then he hit me on the head with those same dishes and broke my head".

\section{Presenting to legal medicine organizations}

Women presenting to legal medicine organizations was associated with: an escalation of violence; despair over her husband correcting her behaviour; wish to intimidate and punish the husband and force him to give up his violent acts; woman's wish to restore her rights; and wish to seek legal retaliation. Participant 3, a 21-year-old woman, said, "I came to the Legal Medicine Organization not for blood money or anything else. I came here only to prove that this man has beaten me up and must be penalized".

Sometimes, women presented to legal centres to rescue their children from the violent situation and to collect documents that would serve as evidence to file for divorce. Participant 11, a 37-year-old woman, said, "He used to beat me constantly and I overlooked it all. Until now when I found that my daughter would also be in danger if I overlooked [his violence] again. I had to come here [the LMO]".

The violation of the basic human rights and dignity of women at home was another reason discussed by the participants. Participant 3 also said, "I felt that my character was being severely damaged if I didn't come to the legal medicine organization and court".

Sometimes, women presented to legal centres out of fear of their husband acting on their threats and their life being in danger. Participant 15 also said, "I have to come to defend myself and my life now, so he won't let himself easily push me again or hit me in the mouth and fill my mouth with blood".

\section{Discussion}

We conducted our study to explain the process of domestic violence against women in Mashhad, Islamic Republic of Iran. The constant comparative analysis of the data revealed inevitable adjustment as the core variable of the study.

According to the participants, violence is rooted in the cultural context in which the individuals live. In Ghana, gender discrimination, traditional norms, women's vulnerability to gender-based oppression and power-oriented behaviours by men were also proposed as the cultural and traditional causes of violence against women (21), which is consistent with our findings. Patriarchal ideas and beliefs have also been proposed as a significant underlying cause of violence against women in the neighbouring country of Turkey (22). In a study conducted in Nigeria, most Nigerian women admitted to the adverse effects of their husband's violence on their health, but believed that the husband has the right to control his wife and that she must obey him at all times (23).

In addition to the underlying factors of violence, excuses would also be given for the violence. According to the participants, these excuses were sometimes the economic problems the family was facing, interference of relatives on both sides (husband's and wife's), or dissatisfaction with how the wife handled housekeeping duties. Socioeconomic turmoil, alcohol consumption (2), low income and husband's low level of education (24), economic problems (11), dissatisfaction of the mother-in-law in the case of Taiwanese women (25) and encouragement by relatives to resort to domestic violence (26) were identified as common causes of violence against women that led to escalation of domestic violence.

The relationship between a woman's education and employment and the degree of domestic violence to which she is subjected does not seem to be a simple linear one. Women with higher levels of education and a greater wealth were less likely to be subjected to domestic violence by their husband in Spain and Malaysia (9), which is consistent with the statements made by the participants of our study. In contrast, in a study on violence against female university professors found that having higher education was not enough to protect women from domestic violence (27). In fact, studies have found that increased income and financial independence in women escalated violence against them in Turkey and Ghana, as their husbands felt they had lost their authority at home $(21,27)$.

According to our participants, repeated violence had made the home a place for the husband to demonstrate power and force the wife to execute his irrational commands. A WHO study examined the different types of violence existing and found that violence often arises 
out of a need for power, and to control of one's wife and exert one's masculinity (2).

Our participant endured violence for different reasons. Sometimes, this endurance went on for a long time and would become intolerable. Fear of the stigma of divorce and the result of non-compliance, and believing in the need for endurance to keep the family together and support the children can be effective in escalating violence and exacerbating its consequences. The notion in some cultures that violence is a private family matter is problematic. For instance, in Ghana, physical aggression of the husband is considered normal behaviour and many women avoid discussing it due to their feelings of shame. Even sexual abuse and harassment between a couple are not defined as violence in the Ghanaian culture (21). In line with the Ghanaian study, a study on Japanese women living in the United States identified cultural factors and institutionalized values such as patience in relation to the family to save face, avoidance of conflict, and cohesion and preservation of the family's unity as the most significant factors inhibiting women from recognizing their husband's behaviour as aggressive and causing them to counteract the efforts made by others to help them (28).

We found that mothers endured their husband's violence because he was the father of their children and they made efforts to preserve their family unit, even at the expense of possible adverse consequences for the children. Witnessing violence against their mothers can damage children and they are the silent victims. They are at risk of two threats: witnessing traumatic events and physical harm to themselves (11).

Violence against women is a violation of universal human rights and a global public health concern, and has several destructive health and social consequences. Therefore, prevention of this devastating phenomenon is a necessity, not only to protect women but also society overall. Violence against women should be prevented and tackled by: strengthening the network of services and social support for women and girls; empowering women through education and economic independence; correcting negative social beliefs and attitudes that value violent masculinity and the inferiority and submission of women; working with religious leaders to spread awareness of religious statements and notes by religious leaders (for example, Imam Baqir) that criticize violence against women and emphasize love and respect for women; and by enacting laws that allow e perpetrators of violence against women and girls to be punished.

\section{Conclusion}

In this study, most of the participants had selected inevitable adjustment as their solution to domestic violence. Improving public and social support for women, promoting respect for the universal human rights of women, enforcing legal protection and putting further penalties on men who mistreat their family appear necessary to reduce domestic violence against women. Future research is recommended to develop actions to improve the life skills of families (particularly problem-solving skills) and empower women to defend their rights.

\section{Acknowledgement}

We thank all the participants for sharing their experiences.

Funding: Iranian Legal Medicine Research Centre (code 2820).

Competing interests: None declared.

\section{Violence domestique à l'égard des femmes en République islamique d'Iran : étude théorique ancrée}

\section{Résumé}

Contexte: Bien qu'il s'agisse d'un phénomène silencieux, la violence à l'égard des femmes a été bien étudiée. Ce type de violence constitue un problème universel présentant des caractéristiques régionales et culturelles différentes; il impose des coûts importants à la société.

Objectifs: La présente étude visait à évaluer les circonstances et les caractéristiques de la violence domestique à l'égard des femmes à Mashhad (République islamique d'Iran).

Méthodes : Il s'agissait d'une étude qualitative reposant sur la méthodologie de la théorie ancrée. Des entretiens individuels semi-structurés ont été menés auprès de 24 femmes sélectionnées à dessein qui avaient été victimes de violence domestique et qui s'étaient rendues à l'organisme de médecine légale de Mashhad pour obtenir de l'aide. Les données ont été analysées selon la théorie ancrée. 
Résultats: L'analyse des données d'entretien a permis de définir sept catégories principales : facteurs de risque de violence ; facteurs de protection contre la violence ; excuses pour la violence ; défis comportementaux et culturels chez les hommes ; ajustement inévitable ; aggravation de la violence ; et consultation des organismes de médecine légale. L'analyse comparative constante des données a permis d'identifier l'ajustement inévitable comme étant la variable centrale de l'étude.

Conclusions: L'adaptation inévitable était la principale stratégie des femmes pour faire face à la violence domestique dont elles étaient victimes. La promotion du respect des droits humains universels des femmes, le renforcement du réseau de services et de soutien social aux femmes et l'application de la protection juridique sont nécessaires pour réduire la violence à l'égard des femmes.

$$
\begin{aligned}
& \text { العنف المنزلي ضد المر أة، جمهورية إيران الإسلامية: دراسة نظرية مؤُصَّلة } \\
& \text { نغمه رزاقى، منير رمضانى، سرور برويزى، سيد محمد طباطبائي نجاد }
\end{aligned}
$$

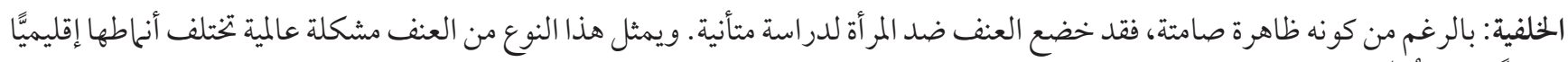

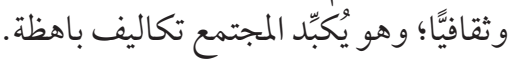

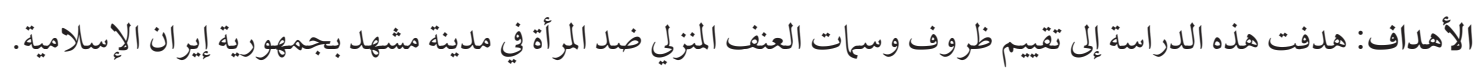

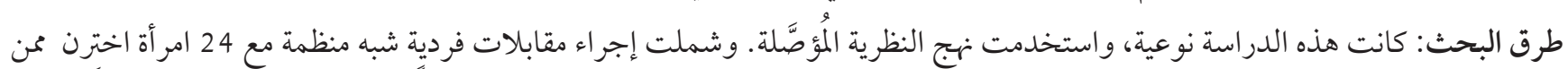

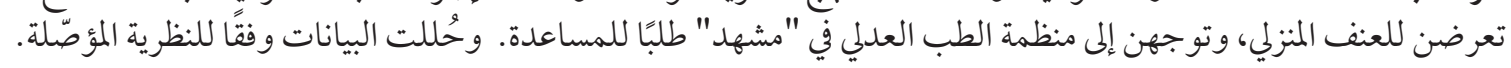

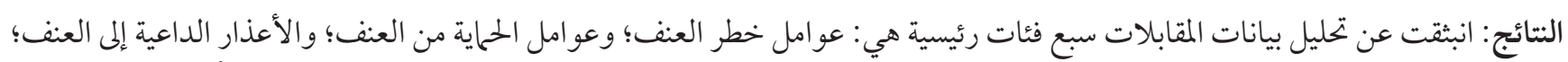

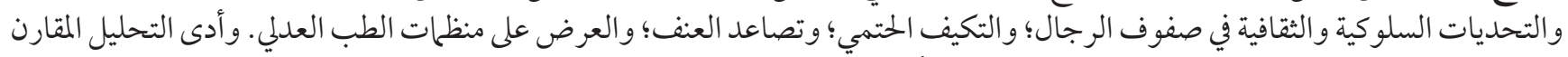

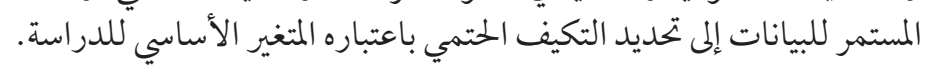

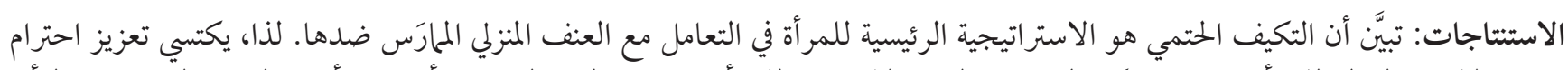

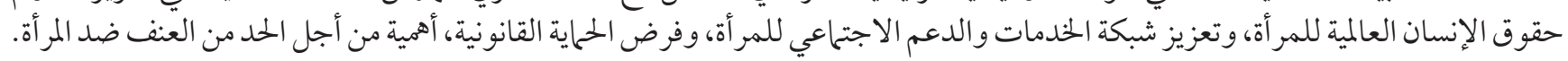

\section{References}

1. Alhabib S, Nur U, Jones R. Domestic violence against women: systematic review of prevalence studies. J Fam Violence. 2010;25(4):369-82. https://doi.org/10.1007/s10896-009-9298-4

2. Global and regional estimates of violence against women: prevalence and health effects of intimate partner violence and non-partner sexual violence. Geneva: World Health Organization; 2013 (https://apps.who.int/iris/handle/10665/85239, accessed 6 December 2013).

3. Tabassum NR, Azim S, Bhuiya A, Ake Persson L. Physical violence by husbands: magnitude, disclosure and help-seeking behaviour of women in Bangladesh. Soc Sci Med. 2006;62(12):2917-29. https://doi.org/10.1016/j.socscimed.2005.12.001

4. Diop-Sidibé N, Campbell JC, Becker S. Domestic violence against women in Egypt - wife beating and health outcomes. Soc Sci Med. 2006;62(5):1260-77. https://doi.org/10.1016/j.socscimed.2005.07.022

5. Western D. Gender-based violence and depression in women: a feminist group work response. Berlin: Springer Science \& Business; 2013.

6. Golmakani N. Domestic violence in pregnancy, outcomes and strategies: a review article. Iran J Obs Gynecol Infertil. 2013;15(42):13-22. https://doi.org/10.22038/IJOGI.2013.571

7. Kamali M, Rahimi Kian F, Mir Mohamad Ali M, Mehran A, Shafiei E. Comparison of domestic violence and its related factors in pregnant women in both urban and rural population in Zarand city, 2014. J Clin Nurs Midwif, 2015;4(2):69-78.

8. Davoudi F, Rasoulian M, Ahmadzad Asl M, Nojomi M. Factors associated with physical domestic violence against women in countries of Eastern Mediterranean Region (EMR): a systematic review and metanalysis. Iran J Psych Clin Psychol. 2013;18(4):261-75. 
9. Shuib R, Endut N, Ali SH, Osman I, Abdullah S, Oon SW, et al. Domestic violence and women's well-being in Malaysia: issues and challenges conducting a national study using the WHO multicountry questionnaire on women's health and domestic violence against women. Proceed Soc Behav Sci. 2013;91:475-88. https://doi.org/10.1016/j.sbspro.2013.08.445

10. Douki S, Nacef F, Belhadj A, Bouasker A, Ghachem R. Violence against women in Arab and Islamic countries. Arch Womens Ment Health. 2003;6:165-71. https://doi.org/10.1007/s00737-003-0170-x

11. Status of Arab women report 2017. Violence against women: what is at stake? Beirut: United Nations Economic and Social Commission for Western Asia; 2017:3.

12. Hajnasiri H, Ghanei Gheshlagh R, Sayehmiri K, Moafi F, Farajzadeh M. Domestic violence among Iranian women: a systematic review and meta-analysis. Iran Red Crescent Med J. 2016;18(6):e34971. https://doi.org/10.5812/ircmj.34971

13. Pournaghash-Tehrani S. Domestic violence in Iran: a literature review. Aggress Violent Behav. 2011;16:1-5. https://doi. org/10.1016/j.avb.2010.12.001

14. Gelles RJ. Public policy for violence against women 30 years of successes and remaining challenges. Am J Prev Med. 2000;19(4):298-301. https://doi.org/10.1016/s0749-3797(00)00245-2

15. Polit DF, Beck CT. Nursing research: generating and assessing evidence for nursing practice. Ninth edition. Philadelphia: Lippincott Williams \& Wilkins; 2012.

16. Boychuch Duchscher JE, Morgan D. Grounded theory: reflections on the emergence vs forcing debate. J Adv Nurs. 2004;48(6):605-12. https://doi.org/10.1111/j.1365-2648.2004.03249.x

17. Struss A, Corbin JM. Basics of qualitative research: techniques and procedures for developing grounded theory. Thousand Oaks, CA: SAGE Publications Inc.; 1998.

18. Streubert H, Carpenter D. Qualitative research in nursing: advancing the humanistic imperative. Philadelphia: Lippincott Williams \& Wilkins; 2007.

19. Grove SK, Burns N. Understanding nursing research: building an evidence-based practice. Fourth edition. Philadelphia: Saunders Co; 2015.

20. Polit DF, Beck CT. Essentials of nursing research: appraising evidence for nursing practice. Philadelphia: Lippincott Williams and Wilkins; 2010.

21. Amoakohene MI. Violence against women in Ghana: a look at women's perceptions and review of policy and social responses. Soc Sci Med, 2004:59:2373-85. https://doi.org/10.1016/j.socscimed.2004.04.001

22. Marshall GA, Furr LA. Factors that affect women's attitudes toward domestic violence in Turkey. Violence Vict. 2010;25(2):26577. https://doi.org/10.1891/0886-6708.25.2.265

23. Ilika AL. Women's perception of partner violence in a rural Ibgo community. Afr J Reprod Health. 2005;9(3):77-88.

24. Kocacik F, Dogan O. Domestic violence against women in Sivas, Turkey: survey study. Croat Med J. 2006;47(5):742-9.

25. Wu TF, Yeh KH, Cross SE, Larson LM. Conflict with mothers-in-law and Taiwanese women's marital satisfaction: the moderating role of husband support. counselling psychologist, 2010;38(4):497-522. https://doi.org/10.1177/0011000009353071

26. Kaur R, Garg S. Domestic violence against women: a qualitative study in a rural community. Asia Pac J Public Health. 2010;22(2):242-51. https://doi.org/10.1177/1010539509343949

27. Kalaca S, Dundar P. Violence against women: the perspective of academic women. BMC Public Health. 2010;10:490. https://doi. org/10.1186/1471-2458-10-490

28. Yoshinhama M. Battered women's coping strategies and Psychological distress: differences by immigration status. Am J Community Psychol. 2002;30:429-52. https://doi.org/10.1023/A:1015393204820 